\title{
Protective Effect of Sodium-Glucose Co-Transporter 2 Inhibitor (Dapagliflozin) on Diabetic Retinopathy in Streptozotocin Induced Diabetes in Rats
}

\author{
HEBA S. SHOUKRY, M.D.*; MAHA M. TAHER, M.Sc.**; AHMED AMIN, M.Sc.**; \\ AHMED ALLAM, M. S c. ** and YARA SAMY, M. S c. ** \\ The Department of Physiology, Faculty of Medicine, Cairo University* and The Department of Pharmacology, \\ Faculty of Pharmacy, Modern Sciences and Arts University**
}

\begin{abstract}
Background: Diabetic retinopathy is a serious diabetic complication as it is considered the most common cause of blindness in diabetes. There is a link between chronic hyperglycemia and the occurrence and progression of diabetic retinopathy.

Aim of Study: To investigate for the effect dapagliflozin, Sodium-Glucoseco-Transporter2 (SGLT2) inhibitor in reduction of diabetic retinopathy.

Material and Methods: Thirty (30) male albino rats (120$150)$ were randomly divided into control $(n=6)$; DM (diabetic non treated group, $\mathrm{n}=10$ ), DM + DAPA (diabetic treated with dapagliflozin for 8 weeks, $n=10$ ). Blood samples and retinal tissues were collected to assess glycated hemoglobin $\left(\mathrm{HbA}_{1_{\mathrm{c}}}\right)$, serum Interleukin 6 (IL-6), lipid profile and retinal expression levels of hydrogen peroxide $\left(\mathrm{H}_{2} \mathrm{O}_{2}\right)$ and Brain Derived Nerve Growth (BDNG) moreover histological assessment was performed.

Results: Diabetes increased all measured parameters while decreased the expression of BDNG. Supplementation of dapagliflozin improved all measured parameters.

Conclusion: This study showed the harmful effect of diabetes on retina which could be mediated by oxidative stress and inflammation. On the other hand, dapagliflozin improved diabetic retinopathy via antioxidant and anti-inflammatory actions also it improved retinal regeneration via increasing the expression of brain derived nerve growth factor.
\end{abstract}

Key Words: Diabetes - Retinopathy - Dapagliflozin - Interleukin 6-Brain derived nerve growth factor.

\section{Introduction}

DIABETES is a highly established chronic disease in the world. Diabetic Retinopathy (DR) is considered a common micro vascular hurdle of diabetes. Early detection and anticipation of retinopathy in diabetic patients is crucial for preventing vision

Correspondence to: Dr. Heba Samy Shoukry, E-Mail: dr.hebasamy.com@gmail.com loss. In order to reach the goal for the efficient medication in diabetic retinopathy, we should seek for understanding the pathogenesis underlying this disease. Although the pathogenesis of DR is unclear, studies have indicated that hyperglycemia, oxidative stress and inflammatory cytokines play a role in the development and the progression of diabetic retinopathy [1]. Hyperglycemia is believed as the first initiating factor in the development of DR, which suggests that strict glycemic control is effective in delaying DR [2]. It is known that hyperglycemia activates protein kinase $\mathrm{C}$, polyol and hexosamine pathways, advanced glycation end products production and these pathways induced mitochondrial dysfunction and endoplasmic reticulum stress and endorse the production of Reactive Oxygen Species (ROS) that promote cellular damage and contribute in the pathogenesis of most diabetic complications [3]. Accumulating evidence has documented that ROS play an important role in the development of diabetic retinopathy. Excess cellular levels of ROS damage of retinal tissue and increased inflammatory process which is believed to play an important role in the development of diabetic retinopathy [4]. Brain Derived Nerve Factor (BDNF) is formed by retinal ganglion cells and in turn plays an essential role in survival of retinal ganglion cells [5]. Diabetes induces imbalance between pro-neurotrophins production and early retinal inflammation. Studies on the levels of neurotrophins might provide a therapeutically effective goal to combat disease progression in diabetic patients [6]. Dapagliflozin sodium-glucose cotransporter 2 inhibitor, it has been shown to improve glycemic index as it works by decreasing re-absorption of glucose in the renal proximal tubule [7]. They have been shown to reduce glyco- 
sylated haemoglobin $\left(\mathrm{HbA}_{1_{c}}\right)$ and fasting plasma glucose levels [8]. The aim of the present study is find out a link between hyperglycemia, increased oxidative stress, inflammation and their effect on brain derived nerve growth factor and the development of diabetic retinopathy and to investigate for the role of dapagliflozin in attenuation of the progression of diabetic retinopathy. This information, which the study sought to provide important for diabetic patients as the prevalence of diabetes may reach 642 million people living worldwide by 2040 .

\section{Material and Methods}

Thirty male albino rats (120-150gm) were obtained and inbred, with veterinary care, in the animal house of MSA University. They were housed in wire mesh cages at room temperature with normal light-dark cycles and maintained on standard rat chow diet and tap water during the four-week experimental period. They were allowed to accommodate for to the environmental conditions 1 week before starting of the experiment that was conducted in accordance with the ethical guidelines of the committee of the Faculty of Medicine, Cairo University during 2017.

\section{Experimental protocol:}

The rats were divided randomly as follows: Control group: Normal control $(n=10)$, diabetic non treated group $(\mathrm{DM})(\mathrm{n}=10)$, diabetic treated with Dapagliflozin $(n=10)$ (Forxiga; AstraZeneca Egypt): Started 6 weeks after induction of DM at a dose of $0.5 \mathrm{mg} / \mathrm{Kg} /$ day corresponding to dose taken by human in type II diabetes orally for 4 weeks.

Induction of diabetes: Streptozotocin (STZ) (Sigma Aldrich, USA)was injected single intraperitoneal injection in a dose of $55 \mathrm{mg} / \mathrm{kg}$ and then diabetic animals with blood glucose level above $300 \mathrm{mg} / \mathrm{dl}$ were rendered diabetic.

Preparation of dapagliflozin: Tablets were curshed, weighed according to the calculated dose then were dissolved in tab water. Each rat received its prepared dose via oral gavage.

\section{Determination of body weight:}

Body weights were measured at the end of the experimental period (10 weeks).

Animals were sacrificed a day after the last treatment under ketamine anesthesia and retina were harvested. From each rat one retina was preserved in foil and kept freezed at $-80^{\circ} \mathrm{C}$ for biochemical analysis, the other retina was kept in formalin (10\%) for histological analysis. Whereas plasma was collected for estimation of blood glucose, $\mathrm{HbA}_{1_{\mathrm{c}}}$, lipid profile and IL-6.

\section{Biochemical measures:}

- Estimation of $\mathrm{HbA}{ }_{1_{c}}$ : It was assessed via rodent hemoglobin $\mathrm{A} 1 \mathrm{c}\left(\mathrm{HbA}_{1_{c}}\right)$ assay kit.

- Estimation of lipid profile: It was assessed via Commercially available kits (BioMed, Cairo, Egypt).

- Estimation of serum IL-6 (Interleukin 6): It was assessed via Elisa kit supplied by (MyBio Source, USA), according to manufacture instruction.

- Estimation of retinal expression of ${ }_{\mathrm{H}_{2} \mathrm{O} 2}$ (hydrogen peroxide): It was assessed via Colorimetric method kit supplied by (Biodiagnostic, Egypt).

- Estimation of retinal expression of BDNG (brain derived nerve growth factor): It was assessed via Western blot kits supplied by Bio Basic Inc. Markham Ontario L3R 8T4 Canada.

- Histological analysis: From each rat, one eye was sectioned into two halves along the horizontal axis. For light microscopy, ocular globes were fixed for $24 \mathrm{hr}$ in $10 \%$ formalin, embedded in paraffin and processed for sectioning at thickness of $5 \mathrm{~m}$ ultiple parallel serial sections at different levels were taken from both halves. Sections were stained with hematoxylin and eosin $(\mathrm{H} \& \mathrm{E})$ then examined microscopically. The sections were analyzed using an Olympus BX5 1 microscope equipped with camera, with magnification 100x in all examined groups. Histological analysis was done in a private histological laboratory.

\section{Statistical analysis:}

Data are expressed as mean \pm SD. Statistical analysis was performed using one-way ANOVA (Graph pad prism, release 7). A $p$-value of $<0.05$ was considered statistically significant Tukey method for multiple comparison $(p<0.05)$.

\section{Results}

Body weight: Results showed significant decrease $(p<0.05)$ in the body weight in the diabetic group (DM), diabetic + Dapagliflozin (DM + DAPA) in comparison to normal control group Fig. (1).

\section{Biochemical measurements:}

- Glycated hemoglobin ( $\mathrm{HbA}{ }_{10}$ ): Results showed significant increase $(p<0.05)$ in the $\mathrm{HbA}_{1 \mathrm{C}} \%$ in $\mathrm{DM}$ group and in DM + DAPA in comparison to normal control group. However there was signif- 
icant decrease $(p<0.05)$ in its percentage in $\mathrm{DM}+\mathrm{DAPA}$ in comparison to diabetic group Fig. (2).

- Cholesterol: According to (Table 1) cholesterol levels showed significant increase in DM, and in $\mathrm{DM}+\mathrm{DAPA}$ in comparison to normal control group. However, there was significant decrease $(p<0.05)$ in the cholesterol levels with DM + DAPA in comparison to DM.

- Triglycerides: Results showed significant increase $(p<0.05)$ in the triglycerides levels in DM and DM + DAPA in comparison to normal control group. However there was significant decrease $(p<0.05)$ in the triglycerides levels with $\mathrm{DM}+$ DAPA in comparison to DM group (Table 1).

- High Density Lipoproteins (HDL): Our results showed significant decrease $(p<0.05)$ in the HDL levels in DM and DM + DAPA in comparison to normal control group. However there was significant increase $(p<0.05)$ in its levels with DM + DAPA in comparison to diabetic group (DM) (Table 1).

\section{B- Assessment of Interleukin 6:}

Results showed significant increase $(p<0.05)$ in Interleukin 6 levels in DM and DM + DAPA in comparison to normal control group. However, there was significant decrease $(p<0.05)$ in its level with DM + DAPA in comparison to diabetic group (DM) (Table 1).
C-Assessment of retinal Hydrogen peroxide level:

Hydrogen peroxide results showed significant increase $(p<0.05)$ in DM and DM + DAPA in comparison to normal control group. However there was significant decrease in the percentage with DM + DAPA in comparison to diabetic group (DM) (Table 1).

\section{$D$ - Assessment of retinal brain derived nerve growth factor levels:}

In this study, we found that BDNF was decreased significantly $(p<0.05)$ in DM and DM + DAPA in comparison to normal control group. However there was significant increase $(p<0.05)$ in its levels with DM + DAPA in comparison to diabetic group (Table 1).

Histological results: In the present work, control group showed normal retinal histology, intact ten layers of retinal structure and no edema is present in retinal tissue Fig. (3A). Diabetic group (DM) fatty changes are the most pronounced. Moreover blood effusion and arteriole remodeling was observed in the loose layers Fig. (3B,C). Administration of Dapagliflozin (DM + DAPA) prevent changes to the structure of the retinal arterioles. The drug was capable of reducing effusion of retinal capillaries and minimizing arteriole remodeling, factors that contribute to the progression of diabetic retinopathy Fig. (3D).

Table (1): Mean \pm SD of serum cholesterol, triglycerides, high density lipoproteins, interleukin 6 (IL-6) and retina expression levels of hydrogen peroxide $\left(\mathrm{H}_{2} \mathrm{O}_{2}\right)$, Brain Derived Nerve Growth factor (BDNG).

\begin{tabular}{lllllll}
\hline Groups & $\begin{array}{c}\text { Cholesterol } \\
(\mathrm{mg} / \mathrm{dl})\end{array}$ & $\begin{array}{c}\text { Triglycerides } \\
(\mathrm{mg} / \mathrm{dl})\end{array}$ & $\begin{array}{c}\text { High density } \\
\text { lipoproteins } \\
(\mathrm{mg} / \mathrm{dl})\end{array}$ & $\begin{array}{c}\text { IL-6 } \\
(\mathrm{pg} / \mathrm{ml})\end{array}$ & $\begin{array}{c}\text { Hydrogen } \\
\text { peroxide } \\
\left(\mathrm{H}_{2} \mathrm{O}_{2}\right)\end{array}$ & $\begin{array}{c}\text { Brain derived nerve } \\
\text { growth factor } \\
(\mathrm{BDNG})\end{array}$ \\
\hline Control & $160.6 \pm 11.3$ & $62.8 \pm 7.63$ & $55.1 \pm 2.86$ & $14.6 \pm 1.01$ & $110.2 \pm 4.9$ & $1.005 \pm 0.008$ \\
DM & $227.1 \pm 14.1 *$ & $107.1 \pm 4.83 *$ & $21.6 \pm 1.21 *$ & $101.7 \pm 6.73 *$ & $584.1 \pm 112.4 *$ & $0.2 \pm 0.03 *$ \\
DM + DAPA & $181.1 \pm 6.18 * @$ & $76.1 \pm 2.32 * @$ & $37 \pm 2.61 * @$ & $75.01 \pm 8.7 * @$ & $207.2 \pm 7.46 * @$ & $0.63 \pm 0.1 * @$ \\
\hline
\end{tabular}

*: Significant $(p<0.05)$ in comparison to control.

(a): Significant $(p<0.05)$ in comparison to DM.

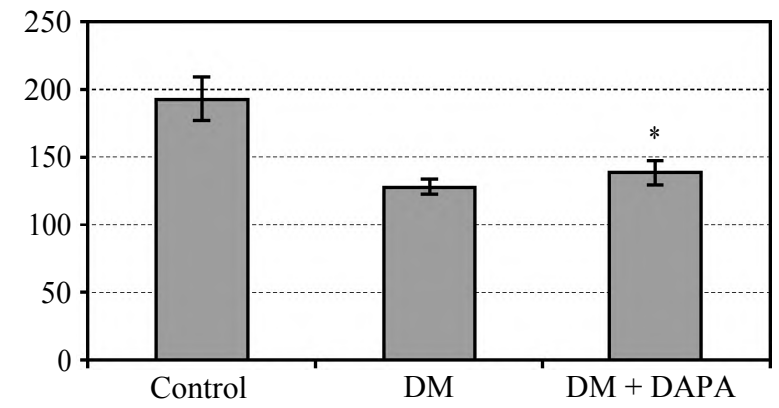

Fig. (1): Mean \pm SD of body weight at the end of the experimental period.

*: Significant $(p<0.05)$ in comparison to control.

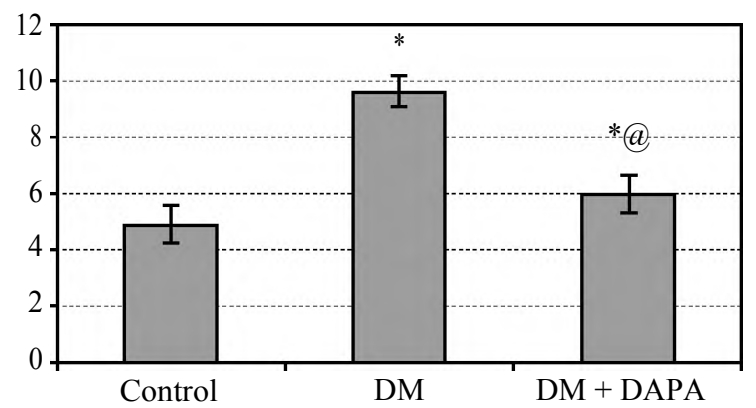

Fig. (2): Mean \pm SD of Glycated hemoglobin $\%\left(\mathrm{HbA}_{l_{c}}\right)$ at the end of the experimental period.

* : Significant $(p<0.05)$ in comparison to control. (a): Significant $(p<0.05)$ in comparison to DM. 

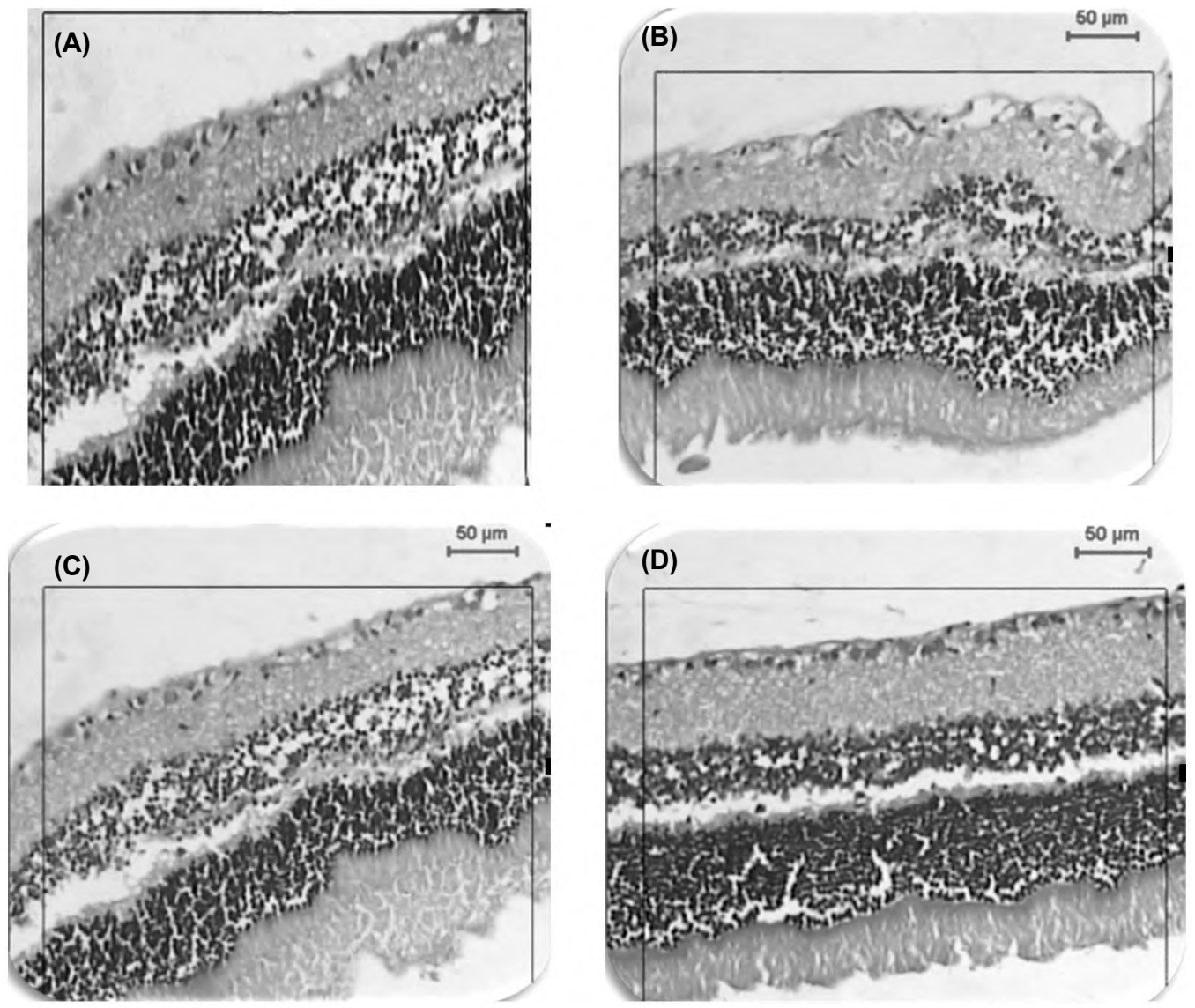

Fig. (3): Photomicrograph pictures of retinal sections stained with H \& E X100. (A) Control group: The retinal structure was continuous, and its capillary structure was normal. (B,C): DM group: The tissue layers of the retina were edematous, and the retina developed telangiectatic vessels (black arrow). Many ganglion cells developed vacuolar degeneration (white arrow). (D): DM \pm DAPA group: Dapagliflozin appeared to prevent changes to the structure of the retinal arterioles.The drug was capable of reducing hyperperfusion of retinal capillaries and minimizing arteriole remodelling, factors that contribute to the progression of diabetic retinopathy.

\section{Discussion}

Accumulating evidence has documented that diabetic retinopathy is a common vascular disorder associated with diabetes. Hyperglycemia associated with diabetes is often accompanied with increased oxidative stress production that causes cellular damage and deterioration of organ function [10] The results of the present study revealed that diabetes decreased body weight and increased retinal oxidative stress and inflammation as detected by increased $\mathrm{H}_{2} \mathrm{O}_{2}$ and increased IL-6, on the other hand diabetic retina showed decreased the expression of brain derived nerve growth factor. Together with histological damage observed by increased retinal fat deposition and bloody accumulation in different fields. This may be an effect of the high lipid profile detected in our result [11]. Proposed that, hyperlipidemia might contribute in DR as it predisposes in endothelial dysfunction and breakdown of the blood retinal barrier [12]. Moreover in diabetes, the sorbitol pathway increases in activity in tissues like retina, kidney, sorbitol does not easily diffuse through cell membranes; as a result, it gathers and grounds osmotic damage [13] Accumulation of ROS can lead to increased vascular permeability and causes damage of vascular endothelium and retinal odema [14]. It has been reported that oxidative stress-induced cell death primarily due to increased necrosis that convinces the expression of an inflammatory genes [15]. In a similar study reported by [16] elucidated that diabetic group showed significant increase in serum glucose, glycosylated haemoglobin $\left(\mathrm{HbA}_{1 \mathrm{c}}\right)$, Total Cholesterol (TC) and retina malondialdehyde (MDA). Our results depicted significant decrease in the level of brain derived nerve growth factor in diabetic group these results are in accordance with [17] as they delectated that level of BDNF was significantly decreased in patients with diabetic retinopathy patients and the retina of diabetic rats as compared to control groups non-diabetic group. The low expression of brain derived nerve growth factor could be attributed to increased oxidative stress which was mentioned by [18] as they observed elevation in the markers of oxidative stress in the 
cerebral cortexes of experimental groups decreased the expression level of brain derived nerve growth factor. From the previous knowledge we could conclude that therapies that target to reduce blood glucose, oxidative stress and lipid levels could be an efficient key to reach the goal of reducing the progression of diabetic retinopathy. In the present work using dapagliflozin the sodium-glucose cotransporter 2 inhibitor resulted in obvious improvement in retinal oxidative stress as detected by a significant decrease in the level of $\mathrm{H}_{2} \mathrm{O}_{2}$ and decreased inflammation by decreased serum level of IL-6. Histopathological examination, showed decreased retinal damage and lowers fatty deposition and blood accumulation in the retina. Dapagliflozin administration for six weeks has been shown to improve diabetic control and reduce blood pressure in patients with type 2 diabetes mellitus, parameters associated with the early stages of vascular remodeling [20]. Moreover results showed that dapagliflozin lowers the plasma lipids and these findings are in accordance to [21]. A study mentioned that treatment with dapagliflozin prevented renal podocyte injury, glomerular pathology, dapagliflozin also decreased renal lipid accumulation. Moreover, renal inflammation and oxidative stress were lower in the dapagliflozin-treated WDfed mice than in the untreated western-fed mice [19]. Results of this study are opposite to [21] as they mentioned that dapagliflozin has no effect of lipid profile in a study on patients, dapagliflozin reduced $\mathrm{HbA}_{1 \mathrm{c}}$ by $0.9 \%$ and body weight by $3.1 \mathrm{~kg}$, mainly attributable to reduction of body water and lean mass but no change was detected in HDL or cholesterol. Results in this study showed that dapagliflozin lowers IL-6 level as these results are in accordance to [22] as they found that Dapagliflozin increased glucose uptake and reduced the secretion of pro-inflammatory chemokines in cardiac endothelial cells. The role of dapagliflozin on brain derived nerve growth factor is still unclear, results in this research depicted significant increase in the expression level of brain derived nerve growth factor and this could be attributed to its role in improvement in all measured parameters. In conclusion, this study accomplished that medication of dapagliflozin is effective in limiting the progression of diabetic retinopathy.

\section{References}

1- MOHAMED Q., GILLIES M.C. and WONG T.Y.: Management of diabetic retinopathy: A systematic review. J. Am. Med. Assoc., 298: 902-16, 2007.

2- CHIU C.J. and TAYLOR A.: Dietary hyperglycemia, glycemic index and metabolic retinal diseases. Prog. Retinal Eye Res., 30: 18, 2011.
3- FIORENTINO T.V., PRIOLETTA A., ZUO P. and FOLLI F.: Hyperglycemia-induced oxidative stress and its role in diabetes mellitus related cardiovascular diseases. Curr. Pharm. Des., 19 (32): 5695-703. 2013.

4- CALDERON G.D., JUAREZ O.H., HERNANDEZ G.E., PUNZO S.M. and De La CRUZ Z.D.: Oxidative stress and diabetic retinopathy: Development and treatment. (Eye (Lond). Aug., 31 (8): 1122-30, 2017.

5- LEWIN G.R. and BARDE Y.A.: Physiology of the neurotrophins. Annu. Rev. Neurosci., 19: 289-317, 1996.

6- MOHAMED R. and EL-REMESSY A.B.: Imbalance of the Nerve Growth Factor and Its Precursor: Implication in Diabetic Retinopathy. J. Clin. Exp. Ophthalmol., Oct., 6 (5): 483, 2015.

7- OTT C., AGNES JUMAR, KRISTINA STRIEPE, STEFANIE FRIEDRICH, MARINA V. KARG and PETER BRAMLAGE ROLAND E. SCHMIEDER: A randomised study of the impact of the SGLT2 inhibitor dapagliflozin on microvascular and macrovascular circulation. Cardiovascular Diabetology, 16: 26, 2017.

8- ZINMAN B., WANNER C., LACHIN J.M., FITCHETT D., BLUHMKI E., HANTEL S., MATTHEUS M., DEVINS T., JOHANSEN O.E., WOERLE H.J., et al.: Empagliflozin, cardiovascular outcomes, and mortality in type 2 diabetes. N. Engl. J. Med., 373 (22): 2117-28, 2015.

9- DING S.L., KUMAR S. and MOK P.L.: Cellular Reparative Mechanisms of Mesenchymal Stem Cells for Retinal Diseases. Int. J. Mol. Sci., 18 (8): 1406, 2017.

10- CALDERON G.D., JUAREZ O.H., HERNANDEZ G.E., PUNZO S.M., De La CRUZ Z.D.: Oxidative stress and diabetic retinopathy: Development and treatment. Eye (Lond), 31 (8): 1122-30, 2017.

11-AGROIYA P., PHILIP R., SARAN S., GUTCH M., TYAGI R.1 and GUPTA K.K.: Association of serum lipids with diabetic retinopathy in type 2 diabetes, Indian J. Endocrinol. Metab., 17 (Supp11): S335-S33, 2013.

12- BENAROUS R., SASONGKO M.B., QURESHI S., FENWICK E., DIRANI M., WONG T.Y., et al.: Differential association of serum lipids with diabetic retinopathy and diabetic macular edema. Invest. Ophthalmol. Vis. Sci., 52: 7464-9, 2011.

13- SAFI SH Z., QVIST R., KUMAR S., BATUMALAIE K. and ISMAIL IKRAM S.B.: Molecular Mechanisms of Diabetic Retinopathy, General Preventive Strategies, and Novel Therapeutic Targets Biomed Res. Int., 801269, 2014.

14- BISWAS S.K.: Does the interdependence between oxidative stress and inflammation explain the antioxidant paradox? Oxidative Medicine and Cellular Longevity, 2016: 9, 2016.

15- HANUS J., ZHANG H., WANG Z., LIU Q., ZHOU Q. and WANG S.: Induction of necrotic cell death by oxidative stress in retinal pigment epithelial cells. Cell Death \& Disease, 4 (12, article no. e965), 2013.

16- ULAS M., ORHAN C., TUZCU M., OZERCAN I.H., SAHIN N., GENCOGLU H., KOMOROWSKI J.R. and SAHIN K.: Anti-diabetic potential of chromium histidinate in diabetic retinopathy rats BMC Complementary and Alternative Medicine The Official Journal of the Interna- 
tional Society for Complementary Medicine Research (ISCMR) 15: 16, 2015.

17- OLA M.S., NAWAZ M.I., EL-ASRAR A.A., ABOUAMMOH M. and ALHOMIDA A.S.: Reduced levels of brain derived neurotrophic factor (BDNF) in the serum of diabetic retinopathy patients and in the retina of diabetic rats. Cell Mol. Neurobiol., 33 (3): 359-67, 2013.

18- HACIOGLU G., SENTURK A.Y., INCE I. and ALVER A.: Assessment of oxidative stress parameters of brainderived neurotrophic factor heterozygous mice in acute stress model, Iran J. Basic Med. Sci., 19 (4): 388-93, 2016.

19- WANG D.1,2, LUO Y.3, WANG X.4,5, ORLICKY D.J.6, MYAKALA K.7,8, YANG P.9,10 and LEVI M.11,12: The Sodium-Glucose Cotransporter 2 Inhibitor Dapagliflozin Prevents Renal and Liver Disease in Western Diet Induced Obesity Mice. Int. J. Mol. Sci., Jan. 3, 19 (1), 2018.
20- OTT C., JUMAR A., STRIEPE K., FRIEDRICH S., KARG M.V. BRAMLAGE P. and SCHMIEDER R.E.: A randomised study of the impact of the SGLT2 inhibitor dapagliflozin on microvascular and macrovascular circulation Cardiovascular Diabetology, 16: 26, 2017.

21- FADINI G.P., BONORA B.M., ZATTI G., VITTURI N.C and MARESCOTTI A.: Effects of the SGLT2 inhibitor dapagliflozin on HDL cholesterol, particle size, and cholesterol efflux capacity in patients with type 2 diabetes: A randomized placebo-controlled trial Cardiovasc Diabetol., 16: 42, 2017.

22- DÍAZ-RODRÍGUEZ E., AGRA R.M., FERNÁNDEZ Á.L., ADRIO B., GARCÍA-CABALLERO T., GONZÁLEZ-JUANATEY J.R. and EIRAS S.: Effects of dapagliflozin on human epicardial adipose tissue: Modulation of insulin resistance, inflammatory chemokine production, and differentiation ability Cardiovascular Research, Volume 114, Issue 2, Pages 336-46, 2018.

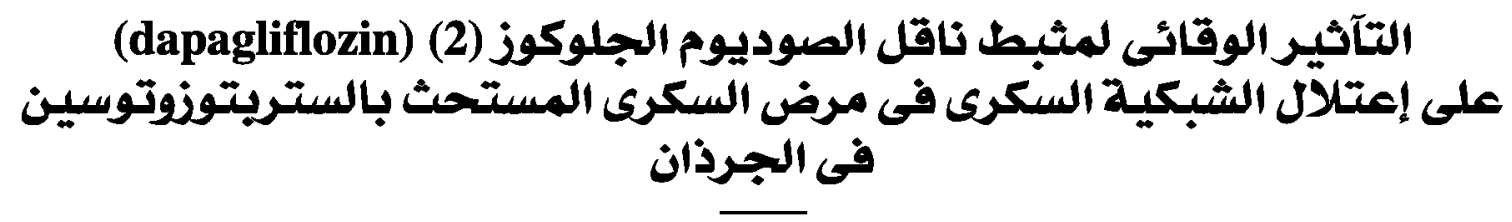

$$
\begin{aligned}
& \text { إعتلال الشبكية السكرى لمرض السكرى يعتبر من الآسباب الاكثر شيوعا للعمى فى مرض السكرى. هناك صلة بين إرتفاع السكر فى المئ }
\end{aligned}
$$

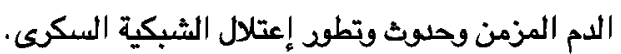

$$
\begin{aligned}
& \text { الهدف من الدراسة: البحث عن تآثير عقار dapagliflozin فى الحد من إعتلال الثبكية السكرى والآلية المستخدمة. }
\end{aligned}
$$

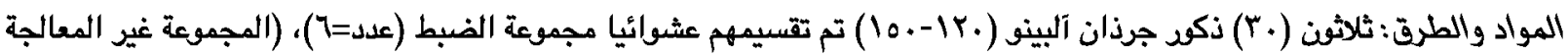

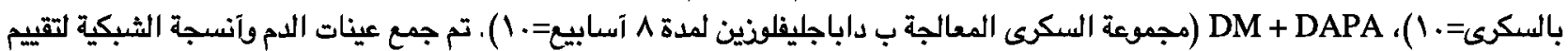

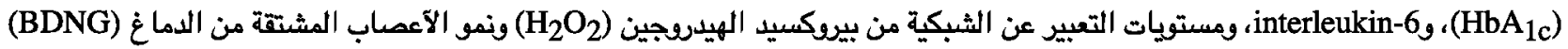

$$
\begin{aligned}
& \text { وتم آيضا عمل فحص ميكروبكوبى لآنسجة الشبكية. } \\
& \text { النتائج: زيادة جميع المعلمات فى مجموعة مرض السكرى مع إنخفاض BDNG. في حين تحسن جميع القياسات مع dapagliflozin. } \\
& \text { الخلاصعة: آظهرت هذه الدراسة الآثار الضارة لمرض السكرى على ثبكية العين والذى يمكن آن يحدث بوبساطة الإجهاد وإلتهاب الآكسدة. }
\end{aligned}
$$

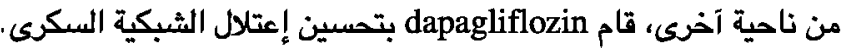

